\title{
IMPACT OF AGRICULTURAL PRACTICES ON THE BOTANICAL COMPOSITION CHANGES AND NUTRITIONAL VALUE OF NATURAL GRASSLAND, TYPE AGROSEIETUM VULGARIS
}

\author{
RADIC, V. ${ }^{*}$ - DRINIC, M. - KRALJ, A. - FIGUREK, A. - KOMLJENOVIC, I. \\ Faculty of Agriculture, University of Banjaluka, Bulevar Vojvode Petra Bojovica 1A \\ 78000 Banjaluka, Bosnia and Herzegovina \\ *Corresponding author \\ e-mail:vojo_radic@yahoo.com \\ (Received $8^{\text {th }}$ Dec 2016; accepted $26^{\text {th }}$ Jan 2017)
}

\begin{abstract}
Natural meadows and pastures are spread over 50\% of agricultural land in Bosnia and Herzegovina and represent the most important resource in the forage production of hilly and mountain areas. The quality of roughage in the ration is very important for the efficient production of meat and milk in cattle and sheep production. Hay is a feed, that has the most variable chemical composition and nutritional value due to the influence of weather conditions, agricultural practices, harvest time and other factors. In this study, the impact of agro-technical measures, harrowing, fertilizing and harvest time on the forage yields, botanical composition and nutritional value of natural grassland, type Agroseietum vulgaris, in Sljivno in Manjaca mountain, were analized. Applied agricultural practices influenced the increase in the proportion of grasses and legumes, which contributed to the improvement of the feed quality. The highest average yield of hay was achieved by applying basic fertilization, two nitrogen applications and harrowing $\left(3.48 \mathrm{t} \mathrm{ha}^{-1}\right)$. All applied agro-technical measures had a positive effect compared to the control group, and the highest yield was $44 \%$ better than the control group.
\end{abstract}

Keywords: agro-technical measures, fertilizers, chemical analizes , forage, grasss, legumes

\section{Introduction}

Grasslands comprise $26 \%$ of the world's total land area and $80 \%$ of agricultural land, and represent a wide variety of ecosystems (Steinfeld et al., 2006; Wright et al., 2006). In the EU (EU25) more then 30\% of the agriculturally utilised area is covered by grassland (Eurostat). There is large variation between countires from the less then 5\% grassland in Finland to more than 75\% in Ireland (Isselstein et al., 2005).

Grassland covers about $40 \%$ of the agricultural area in Europe (European Commission, 2006) and it supplies most of the feed used by cattle and other ruminants. Among the various constituents of herbage quality that are important for ruminants is the need for sufficient amounts of minerals in the diet to ensure good health and performance (Underwood and Suttlen, 1999). However, it is a challenge to manage the mineral supply of ruminants fed on grassland, because mineral concentrations in the herbage are influenced by a number of factors including species composition of the sward (Kuusela, 2006), time of the year (Høgh-Jensen et al., 2006) and fertilization (Soder and Stout, 2003).

Over $50 \%$ the of total agricultural land is under natural meadows and pastures in Bosnia and Herzegovina. Most of these areas are located in hilly and mountain region. Production in these areas is characterized by low yields and poor quality of roughage (Gatarić et al., 2014). The lack of implementation of agro-technical measures is the reason of low and unstable yields and poor quality of forage (Dubljević, 2007). 
Natural grasslands belong to the most widespread meadow-pasture communities in the mountain region of Serbia (Lazarevic et al., 2009). They extend in areas where moisture is sufficient for the growth of grass, and where climatic, anthropogenic and other environmental conditions inhibit the growth of trees and/or limit the suitability of the land for food crops (White, 1983). Natural grasslands are plant communities which are often dominated by grasses and herbaceous plants. Especially valuable component of natural grasslands are legumes. Legumes are a major carrier of forage quality of a grassland, but they are rarely present in higher percentage. Native forage is the only nutrient and energy source for livestock because stored hay or concentrated livestock feed are unavailable (Wen et al., 2013). The nutritive value of the forage not only determines its nutritive composition, but also provides an estimate of its quality (Burns, 2011). The plants that are practically worthless for animal nutrition are also seen in the grasslands (Alibegovic - Grbic, 2005).

The ability of grassland to provide forage as the important source of nutrients to support livestock productivity depends on both its aboveground net primary productivity (ANPP) and its nutritional value (Snyman, 2002). The seasonal distributions of precipitation and temperature contributed more in terms of affecting ANPP and forage nutritional value than their annualized sums, especially for forage digestibility (CDOM) and metabolizable energy (ME); thus the dynamic pattern of vegetation productivity and nutrients should be estimated according to the temporal distribution of climatic factors (Rena et al., 2016). The functional diversity of native grasses also appears in their contrasting responses in productivity, when grown in monocultures, to $\mathrm{N}$ supply and to cutting frequency (Pontes et al., 2007).

The significant proportion of dry and wet grasslands can only be preserved with the adequate maintenance. As part of grassland management, in connection to grazing, examining over-grazing (Kiss et al., 2011). Kosic et al. (2014) made research regarding changes in management of pastures underlie variations in quantity and nutritive value (chemical composition and in-vitro digestibility) of forage. The research outcomes also highlighted that the variables which define the quantity and quality of forage, follow a main gradient related to the phenology of the grassland community.

Házi et al. (2012) examined the species combinations of the grassland, which are important for the survival of the grassland. They found that species composition on the overgrazed are seemed to be stable, and number of grazing animals maintains the diversity of the grassland if their number was determined according to the distribution of the yield.

Several authors (Stevanovic et al., 2004; Nesic et al., 2004; Vuckovic et al., 2004; Alibegovic et al., 2004) in their research concluded that proper fertilization of meadows and pastures with mineral and organic fertilizers and rational exploitation, enable increase of the hay yield, up to several times (up to $20 \mathrm{t} \mathrm{ha}^{-1}$ ). At the same time, this improves the quality of the forage. Nitrogen is one of the most important nutrients for achieving high yields of natural grasslands.

Vitousek and Howarth (1991), Frink et al. (1999), LeBauer and Treseder (2008) point out that the nitrogen is usually the limiting factor for high production of natural grasslands. Two main factors, the quality of the vegetation cover and yield of fodder determine the economic significance of natural grasslands (Kojic et al., 2001). The chemical composition of the dry matter of natural grasslands significantly influences the quality of forage, and it is greatly dependent on environmental factors, floristic composition and phases of plant development (Ivanovski et al., 2004). Hay represents a 
forage with the most variable chemical composition and nutritional value due to the influence of various factors. However, in modern cattle production, it is necessary to add hay in small quantities in the diet in order to ensure normal process of rumination. The stage of plant development and phenophases at the time of mowing or preservation influence the nutritional value of roughage. Maturation of plants reduces the proportion of energy, protein, calcium, phosphorus and other nutrients, while increases the level of crude fiber. However, increasing levels of crude fiber tend to increase the content of lignin that is indigestible and inaccessible for the animal and as a result is reduced energy value of feeds. This happens because the maturation of plants reduces the contribution of leaf, and increases the proportion of stem (Grubic and Adamovic, 2003).

The climate is an important factor that can affect the chemical composition and nutritional value of forage. High temperatures, especially during the night, accelerating the maturation of plants, and on this occasion more fiber and less digestible carbohydrates are formed. More digestable carbohydrates and proteins in plants are accumulated in cold weather conditions. Also, dry weather leads to stress in plants, the plants grow more slowly and the fiber content is increased in them. This leads to a reduction of nutritional value of forage. The composition of the soil has a great impact on the mineral content in forages (Grubic and Adamovic, 2003). The increased proportion of nitrogen can lead to an increase in the total protein in the roughage.

The aim of this study is to determine the yield and nutritional value by using different agricultural practices. Based on the results, the measures should be proposed to repair natural grasslands and achieve greater production of good quality of forage.

\section{Materials and methods}

\section{Study area}

The study was conducted on the natural grassland, type Agrostietum vulgaris, south of Banja Luka, on the site Sljivno at Manjaca mountain (N $44^{\circ} 40 ' 57$ "E $16^{\circ}$ 59'38", $513 \mathrm{~m}$ above sea level). Climate parameters (presented in Table 1) were monitored during the two growing seasons. On the basis of the mean monthly air temperature and precipitation can be noted that the average monthly temperature in 2012, in June and July, was significantly higher than in 2013. The amount of precipitation in the vegetation period in 2012, also was higher, which was suitable for the production of forage.

Table 1. The average monthly temperatures and monthly sums of precipitation in the vegetation period

\begin{tabular}{lcccccccc}
\hline Month & III & IV & V & VI & VII & VIII & IX & X \\
\hline Temperature ${ }^{\circ} C(2012)$ & 9.7 & 13.1 & 16.6 & 23.7 & 26.0 & 25.2 & 19.5 & 12.9 \\
\hline Temperature ${ }^{\circ} C(2013)$ & 6.3 & 13.9 & 17.1 & 21.1 & 23.7 & 24.2 & 17.2 & 13.1 \\
\hline Temperature ${ }^{\circ} C(1961-2013)$ & 6.6 & 11.2 & 16.1 & 19.7 & 21.3 & 20.8 & 16.3 & 11.2 \\
\hline Precipitation $l m^{-1}(2012)$ & 5.0 & 103.0 & 167.9 & 69.8 & 53.2 & 1.8 & 92.0 & 87.6 \\
\hline Precipitation $l m^{-1}(2013)$ & 88.5 & 62.9 & 119.5 & 54.2 & 27.4 & 36.2 & 69.7 & 67.6 \\
\hline Precipitation $l m^{-1}(1961-2013)$ & 79.6 & 89.4 & 93.6 & 112.0 & 92.5 & 85.9 & 93.3 & 78.9 \\
\hline
\end{tabular}


The results of chemical analysis of soil showed that the soil at the site of performing experiments was very acidic, but it had a high humus content. Phosphorus and potassium were determined by AL-method. The low phosphorus content was noted, and the soil was well supplied with potassium (Table 2).

Table 2. The results of chemical soil analysis

\begin{tabular}{cccccccccc}
\hline \multicolumn{2}{c}{$p H$ reaction } & $\mathrm{CaCO}_{3}$ & Humus & $\mathrm{P}_{2} \mathrm{O}_{5}$ & $\mathrm{~K}_{2} \mathrm{O}$ & $\mathrm{C}$ & $\mathrm{Mg}$ & $\mathrm{Zn}$ & $\mathrm{Cu}$ \\
\hline $\mathrm{H}_{2} \mathrm{O}$ & $\mathrm{KCl}$ & $\%$ & $\%$ & $m g / 100 g$ & $m g / 100 g$ & $\begin{array}{c}(m g \\
\left.\mathrm{kg}^{-1}\right)\end{array}$ & $\begin{array}{c}(m g \\
\mathrm{kg}^{-1}\end{array}$ & $\begin{array}{c}(\mathrm{mg} \\
\left.\mathrm{kg}^{-1}\right)\end{array}$ & $\begin{array}{c}(m g \\
\left.\mathrm{kg}^{-1}\right)\end{array}$ \\
\hline 3.7 & 4.37 & 1.29 & 6.03 & 4.43 & 15.36 & 514.4 & 98.09 & 5.94 & 10.53 \\
\hline
\end{tabular}

\section{Experimental design and data collection}

The experiment was set up as a random block system in four repetitions (Diagram 1), with the size of experimental unit of $12 \mathrm{~m}^{2}(8 \times 1,5 \mathrm{~m})$, and the following treatments:

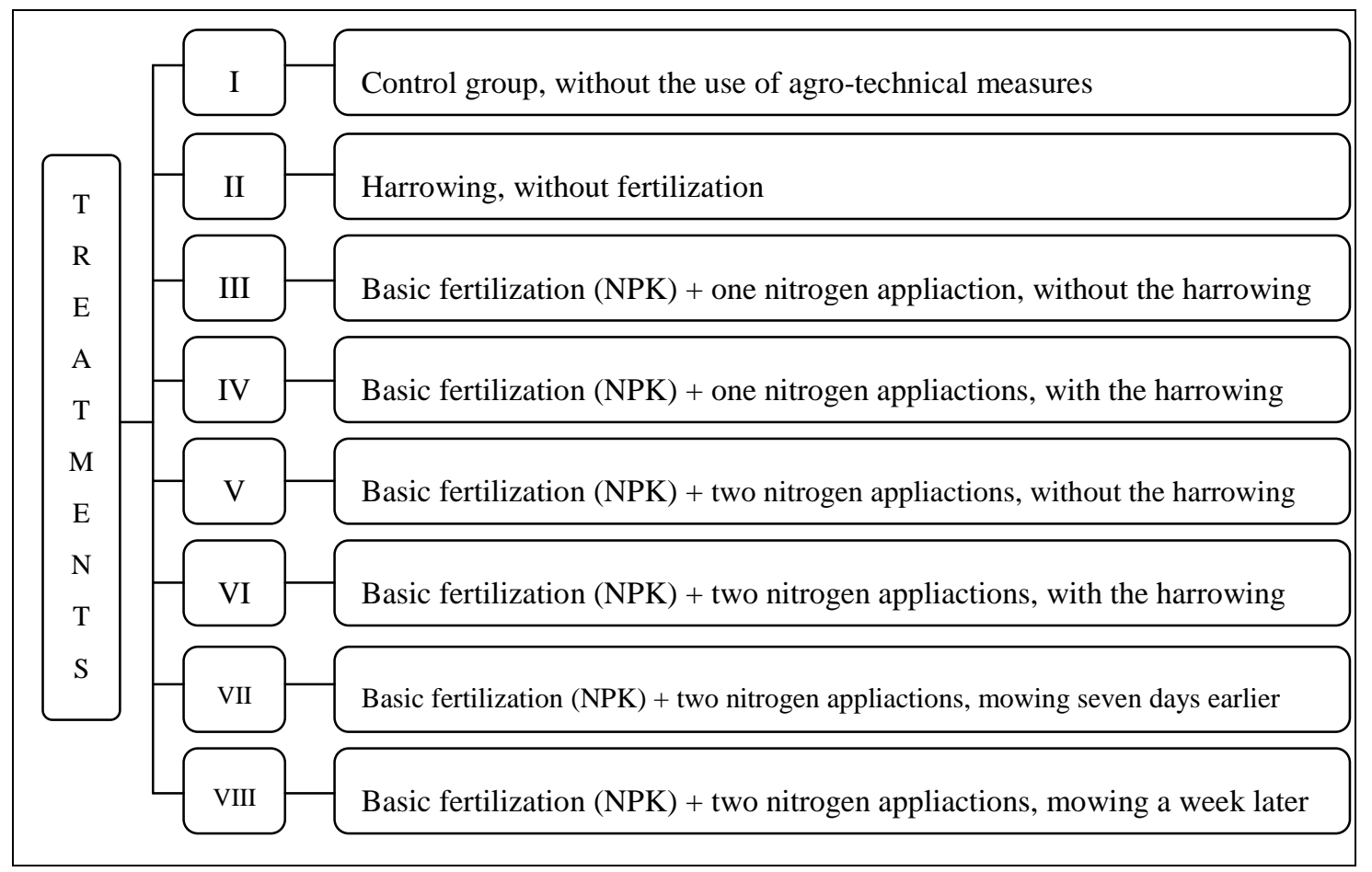

Diagram 1..Experimental design

Agro-technical measure, harrowing was carried out in early spring before the growing season. Basic fertilization (8:16:24 NPK) was thrown by hand with a standard fertilization of $300 \mathrm{~kg} \mathrm{ha}^{-1}$. Nitrogen fertilizer KAN $(27 \% \mathrm{~N})$ was used for the supplemental fertilization, with the norm of $200 \mathrm{~kg} \mathrm{ha}^{1}$. The samples of the first six tretments were taken at the time of the optimal growth stage, ie. in the stage of full flowering. The samples of the treatment VII were taken seven days earlier, and treatment VIII seven days later. 


\section{Analytical methods}

Green mass yield was determined by measuring the total weight of experimental units after mowing. Involvement of grass (fam. Poaceae), legumes (fam. Fabaceae), herbaceus plants and other plants in the total biomass were determined from the measured samples $(1 \mathrm{~kg})$.

The samples were taken from all treatements and repetitions to determine the hay yield and chemical composition of dry matter. After mowing, $1 \mathrm{~kg}$ of the green mass (from each plot) was taken and left to dry in a natural temperature to hay. The samples were measured to determine the drying factor. The hay yield per unit area was calculated by multiplying the drying factor and green mass yield. The quality of dry matter was determined by analyzing its chemical composition in the Laboratory for feed quality control, Faculty of Agriculture, University of Novi Sad. The content of crude protein, crude fiber, ash, NDF, ADF, P and K was determined by this analysis. All parameters are determined for each experimental unit, processed and presented as average values according to treatements. The results of biometric measurements are processed by Windows PC applications: Statistical Package for Social Sciences and Excel.

\section{Results and discussion}

The results of involvement of certain plant species on natural grassland, type Agrostietum vulgaris, are presented in Diagram 2. Based on the obtained data it can be concluded that the application of agro-technical measures on natural grasslands led to changes in phytocenologic composition as compared to the control group. Applied agrotechnical measures affected the increase in the proportion of grasses and legumes, and the decrease in the share of herbaceus and other plants.

With regard to research year, the smallest changes in plant community composition were found in the control variant, with no applied agro-technical measures. In 2013, applied agro-technical measures had the greatest impact on increasing the proportion of legumes. The largest effect on the change of botanical composition had treatments V and VI. Data of hay yield with respect to study years and treatements of agricultural measures are shown in Diagram 3. The average annual values, as well as two-year average per treatment were calculated based on data of four replications. Two-factor analysis of variance, F-test statistics showed that there were statistically significant differences between the treatments ( $\mathrm{p}<0.01)$. Using Dancan post-hoc test $(\mathrm{p}<0.01)$ was found between which treatments there was a statistically significant difference. Among the treatments labeled with the same letter there were no statistically significant differences. Looking at the two-year yield of hay, it can be seen that the highest yields were in V and VI treatments. Control group (I) had the lowest hay yield. There was a highly significant statistical difference in the hay yield between the control goup and the treatments with applied agro-technical measures.

In the examined period, the highest average hay yield of $3.66 \mathrm{t} \mathrm{ha}^{-1}$ was achieved in the treatment VI in 2013, while the lowest average hay yield was $2.07 \mathrm{t} \mathrm{ha}^{-1}$ and it was achieved in the control group. Looking at the results at the level of two years, there was a coincidence. The significant yield increase compared to the control group (variant I) was demonstrated by the applied treatments (in both years). The total hay yield was mostly increased compared to the control group, $44 \%$ in the variant VI and $43 \%$ in the variant V, and at least, $8 \%$ in the variant II and $13 \%$ in the variant IV. Analyzing the treatments with and without harrowing it can be concluded that the application of this agro-technical measure led to increased yield of about $10 \%$. 

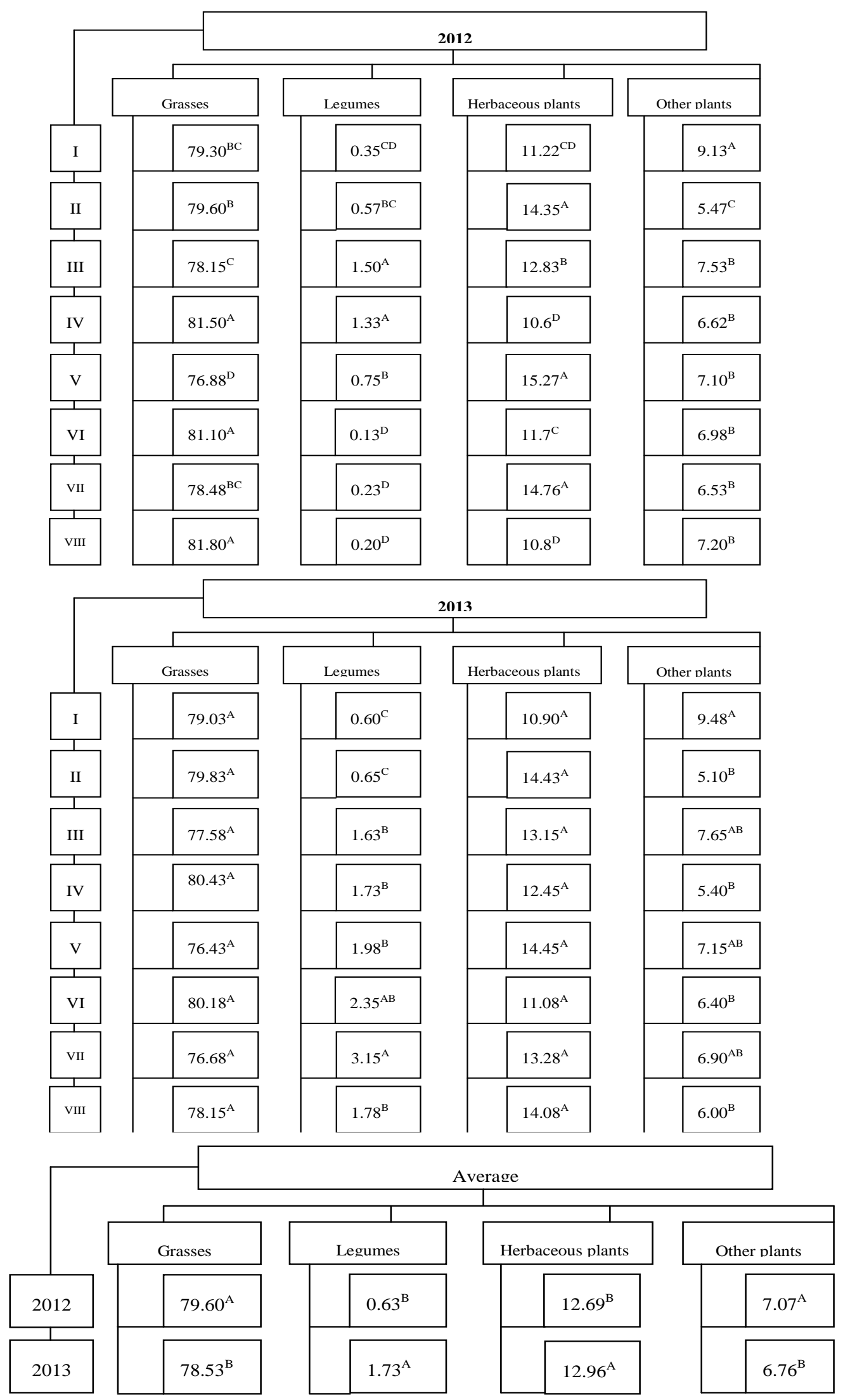

Diagram 2. The share of grasses, legumes, herbaceous and other plants within the natural grassland, \%. ${ }^{A B C}$ Values denoted by the same letter are not significantly different at the $p=0.01$ level of probability (Duncan's Multiple Range Test). 


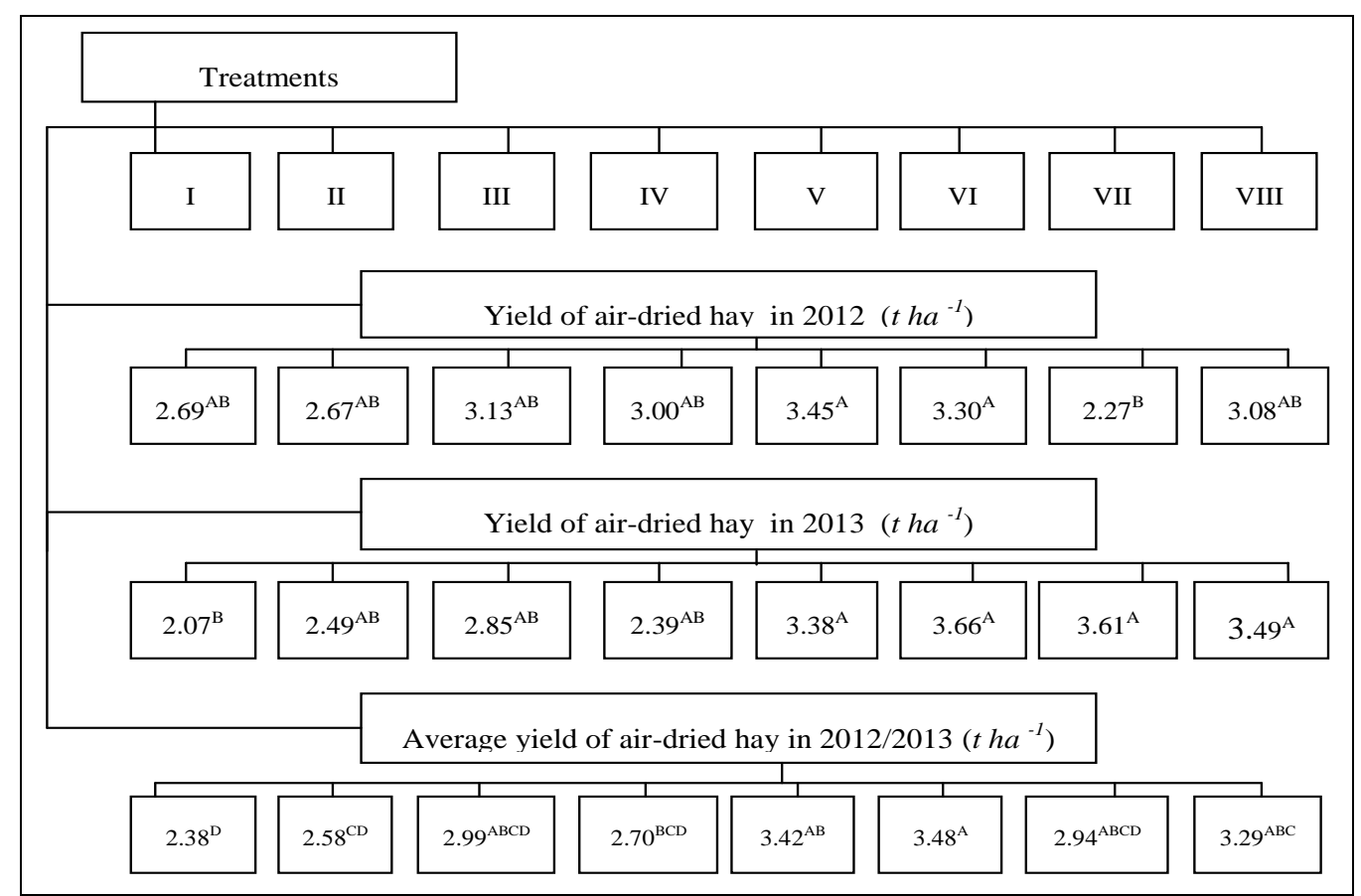

Diagram 3. The average yield of air-dried hay according to agro-technical measures and study years. ${ }^{A B C}$ Values denoted by the same letter are not significantly different at the $p=0.01$ level of probability (Duncan's Multiple Range Test).

Nitrogen fertilization of natural grasslands has great significance because its application increased forage and crude protein yield, stimulates the growth and grass tillering, increases the density of grass cover, extends the vegetation and maturation of plants (Dubljević, 2007). Vuckovic et al. (2010) concluded that the application of $1 \mathrm{~kg}$ NPK fertilizer on natural grassland, type Agrosidetum vulgaris, can increase the hay yield up to $16,2 \mathrm{~kg}$ in Western Serbia. Djuric et al. (2007) recognized that the fertilization of natural grasslands increases the proportion of high-quality plants on the lawn, which results in greater production of proteins. Nitrogen supply has a well-known positive effect on above-ground productivity of forage plants (Nevens and Rehuel, 2003; Kirkham and Wilkins, 1994), but usually has little direct or variable effects on the energy value of herbage (Salette, 1982).

Interactions between climate and topography create a spatial grassland mosaic of coexisting plant species, which results in variations in palatability and nutritive value for grazing ruminants (Roukos et al., 2011).

The results of the chemical composition of plant dry matter are shown in Diagram 4. The protein content of the natural grasslands ranged 7.06 to $8.24 \%$, while the crude fiber content was $30.08-34.60 \%$. In the second year, there was an increase in protein and crude fiber content and a decrease in ash content. Chemical composition of hay corresponds to the composition and quality of natural grassland, as well as its botanical composition (Prentović et al., 2007). In study of Radic et al. (2014) protein content at $8 \%$ on a natural grassland was found. Of the total nitrogen content in green feeds about $70-90 \%$ are true protein, and $10-$ $30 \%$ are non-protein nitrogen compounds. Detergent method is used for the separation of soluble and insoluble carbohydrates in the diet of ruminants, and thus neutral detergent fiber (NDF) and acid detergent fiber (ADF) are separated (Van Soest et al. 1991). NDF is composed of hemicellulose, cellulose and lignin, and ADF of cellulose and lignin (Đorđević et al., 2009). 

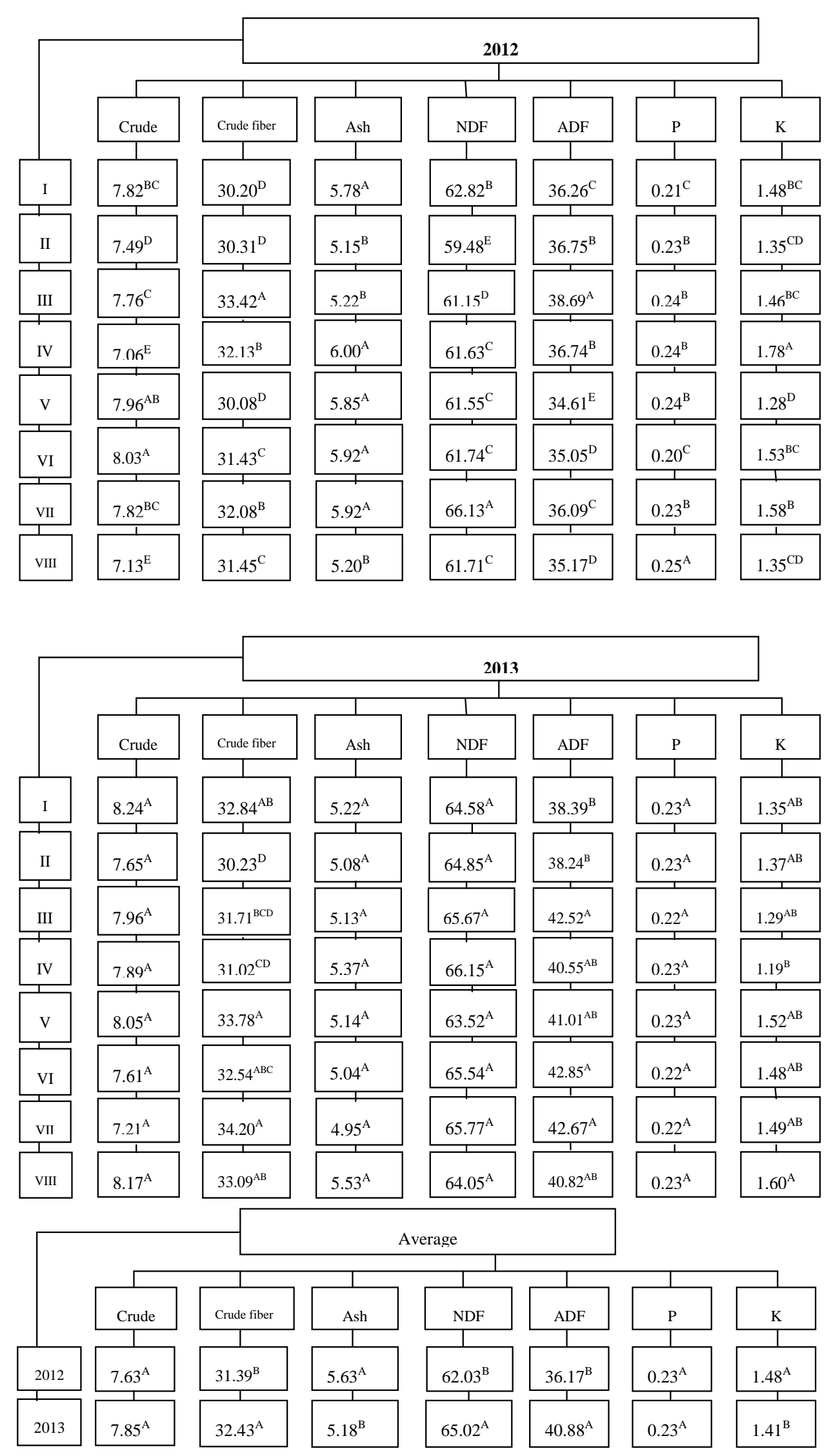

Diagram 4. The nutritive value of hay (\%). ${ }^{A B C}$ Values denoted by the same letter are not significantly different at the $p=0.01$ level of probability (Duncan's Multiple Range Test). 
Hemicellulose and cellulose, which are components of the cell walls are largely fermented in the rumen to acetic acid and less to propionic acid. Carbohydrates that come from cell content mainly fermented to propionic acid. NDF is important to stimulate rumination and chewing, to buffer the rumen content, maintaining rumen wall as well as maintaining the percentage of fat in milk (Fox et al., 1990; Grubic et al., 1999). In the case of an increased proportion of ADF there is a reduction in the level of digestible energy.

Changes in forage nutrient contents may be related with changes in soil nutrient contents, botanical composition and interactions among plants. Alpine grassland degradation has been shown to decrease soil quality (Yang et al., 2009; Wen et al., 2013). Forage quality can also be influenced by soil quality (Čop et al., 2009; Malhi et al., 2010; Verlinden et al., 2010). Several previous studies have shown that botanical composition can affect forage nutritive value (Deak et al., 2007; Biewer et al., 2009; Perbandt et al., 2010). It is known that a greater share of the soil resources will be taken by more than less competitive pe- rennial grass species (Saint Pierre et al., 2004).

The variability of species assemblage in semi-natural grasslands depends on environmental factors (Belesky et al., 2002; Catorci et al., 2011, 2013; Szentes et al., 2012) and on grazing management and history (Holechek et al., 1995; Belesky et al., 2002b). These interacting factors create a mosaic of plant communities, which results in variations in palatability and nutritive value for grazing ruminants (Roukos et al., 2011). For instance, the decrease in herbage use due to pasture abandonment or improper management causes the spread of taller and less digestible vegetation (Louault et al., 2002).

\section{Conclusions}

Based on the research of botanical composition, yield and quality of forage production on natural grasslans, type Agroseietum vulgaris, the following conclusions can be performed:

Research of botanical composition of natural grassland, type Agroseietum vulgaris in Manjaca have shown that the grasses are the most frequent $(79.3 \%)$ are less represented herbaceous plants (11.22\%) and other plants (13.9\%), and at least legumes $(0.35 \%)$.

Forage production using the agro-technical measures, fertilization and harrowing can be increased from $2.38 \mathrm{t} \mathrm{ha}^{-1}$ at $3.48 \mathrm{t} \mathrm{ha}^{-1}$, which represents an increase of $44 \%$.

Natural grassland fertilization with mineral fertilizers increased the proportion of quality grasses and legumes, and reduce the presence of other plants.

The value of roughage in ruminant nutrition is determined by the dry matter yield per unit area and the nutritional value of that dry matter.

Protein content did not show significant differences, but the differences can be expected in the coming period due to changes in floristic composition.

The percentage of protein of natural grasslands ranged 7.06 to $8: 24 \%$, while the crude fiber content was $30.08-34.60 \%$. In the second year of the examination there was an increase in protein content and crude fiber and a decrease in ash content.

Application of appropriate agricultural measures, with the proper care and utilization of natural meadows and pastures, can lead to significant progress in the production and quality of forage, and thus improve livestock in the mountain areas of Bosnia and Herzegovina. 
Acknowledgements. We would like to convey our gratefulness to projects "Research, education and knowledge transfer promoting entrepreneurship in sustainable use of pastureland/grazing" and "Grassland management for high forage yield and quality in the Western Balkans“" (under HERD - Norwegian Programme for Higher Education, Research and Development 2010-2014, coordinated by the University of Life Sciences at As, Norway) that are financed the research.

\section{REFERENCES}

[1] Alibegović - Grbić, S. (2005): Unapređenje proizvodnje krme na prirodnim travnjacima. Univerzitet u Sarajevu. Poljoprivredni fakultet. Sarajevo.

[2] Alibegović-Grbić, Senija. Čivić, H. Bezdrob, M. (2004): Uticaj primjene nižih doza azota i faze razvoja biljaka pri kosidbi na prinos suve materije i sirovih proteina sa travnjaka. Acta Agriculturae Serbica 17:497-293.

[3] Belesky, D.P. Fedders, J. M. Ruckle, J. M. Turner, K. E. (2002a): Bermudagrass-white clover-bluegrass sward production and botanical dynamics. - Agronomy Journal 94: 575584.

[4] Belesky, D.P. Feldhake, C.M. Boyer, D. (2002b): Herbage production and botanical composition of hill pasture as a function of clipping and site features. - Agronomy Journal 94: 351-358.

[5] Biewer, S.M. Wachendorf, T. Fricke (2009). Development of Canopy Reflectance Models to Predict Forage Quality of Le-gume-Grass Mixtures. - Crop Science 49: 19171926.

[6] Burns, J.C. (2011). Advancement in Assessment and the Reassessment of the Nutritive Value of Forages. - Crop Science 51: 390-402.

[7] Catorci, A. Antolini, E. Tardella, F.M. Scocco, P. (2013): Assessment of interaction between sheep and poorly palatable grass: a key tool for grassland management and restoration.-Journal of Plant Interactions. doi:10.1080/17429145.2013.776706

[8] Cop, J. Vidrih, M. Hacin, J. (2009): Influence of cutting regime and fertilizer application on the botanical composition. yield and nutritive value of herbage of wet grasslands in Central Europe. - Grass and Forage Science 64: 454-465.

[9] Deak, A.D.D. Archibald, M. Sanderson, A. Hall, M.H. (2007): Production and Nutritive Value of Grazed Simple and Complex Forage Mixtures. - Agronomy Journal 99: 814821. DOI: 10.1016/j.compag.2010.04.010

[10] Dubljević, R. (2007): Uticaj đubrenja azotom na proizvodne osobine livade tipa Agroseietum vulgaris u brdskom području polimlja. - Zbornik radova. XI Simpozijum o krmnom bilju Republike Srbije 44(1): 355-360.

[11] Đorđević, N., Grubić, G., Makević, M., Jokić, Ž. 2009. Nutrition of domestic and farmed animals. - Faculty of agriculture, Belgrade.

[12] Đurić, Milena. Milić, Vesna. Ćurčić. S. Veljković Biljana (2007):Produktivnost i kvalitet bimase prirodnih travnjaka Moravičkog okruga. - Acta Agriculturae Serbica. Vol. XII. 62 23: 61-68.

[13] European Commission (2006) Eurostat. Available at: http://ec.europa.eu/eurostat

[14] Eurostat (2015): Database - Crop statistics by NUTS 2 regions (from 2000 onwards). http://appsso.eurostat.ec.europa.eu/nui/show.do?dataset=agr_r_acs\&lang=en

[15] Fox, D.G. Tylutki, T.P. Van Amburgh, M.E. Chase, L.E. Pell, A.N. Overton, T.R. Tedeschi, L.O. Rasmussen, C.N. Durbal, V.M. (1990): The Net Carbohydrate and Protein System for evaluating herd nutrition and nutrient excretion. - Animal Science Dept. Mimeo 213. Cornell University. Ithaca. NY. 14853.

[16] Frink, C.R. Waggoner, P.E. Ausubel, J.H. (1999): Nitrogen fertilizer: retrospect and prospect.- PNAS 96:1175-1180. 
[17] Gatarić, Đ. Drinić, Milanka. Radić, V. Kral,j A. (2014): Proizvodnja na oranicama i hranljiva vrijednost krmnog bilja. Univerzitet Istočno Sarajevo. - Poljoprivredni fakultet:305

[18] Grubić, G. Adamović, M. (2003): Ishrana visokoproduktivnih krava. - PKB. Agroekonomik. Beograd

[19] Grubić, G. Đorđević, N. Radivojević, M. (1999): Fizičke osobine vlakana u obrocima za krave. - Arhiv za poljoprivredne nauke $\mathrm{N}^{0} 210$. Vol. 60. Br. 1 - 2: $61-72$.

[20] Házi, J. Penksza, K. Bartha, S. Hufnagel, L. Tóth, A. Gyuricza, Cs. Szentes, Sz. (2012): Cut mowing and grazing effects with grey cattle on plant species composition in case of Pannon wet grasslands. - Applied Ecology and Enviromental Research 10: 223- 231.

[21] Høgh-Jensen, H. Nielsen, B. Thamsborg, S.M. (2006): Productivity and quality. competition and facilitation of chicory in ryegrass / legume-based pastures under various nitrogen supply levels. - European Journal of Agronomy 24: 247-256.

[22] Holechek, J.L. Pieper, R.D. Herbel, C. H. (1995): Range management principles and practices. - Prentice Hall, Englewood Cliffs, New Jersey.

[23] Isselstein, J. Jeangros, B. Pavlu, V. (2005): Agronomic aspects of biodiversity targeted management of temperate grasslands in Europe - A review, Agronomy Research 3(2):139-151.

[24] Ivanovski, P.R. Prentović, Tatjana. Stojanova, Marina. (2004): Uticaj đubrenja na hemijski sastav sena kod prirodnog visokoplaninskog travnjaka. - Acta Agriculturae Serbica 17:257-261.

[25] Kirkham, F.W. Wilkins, R.J. (1994): The productivity and response to inorganic fertilizers of species-rich wetland hay meadows on the Somerset Moors: the effect of nitrogen, phosphorus and potassium on herbage production. - Grass and Forage Science 49:163-175.

[26] Kiss, T. Lévai, P. Ferencz, Á. Szentes, Sz. Hufnagel, L. Nagy, A. Balogh, Á. Pintér, O. Saláta, D. Házi, J. Tóth, A. Wichmann, B. Penksza, K. (2011): Change of composition and diversity of species and grassland management between different grazing intensity - in Pannonian dry and wet grasslands. - Applidied Ecology and Environmental Research 9(3): 197-230.

[27] Kojić, M. Mrfat-Vukelić, S. Dajić, Z. Vrbničanin, S. Fabri, S. (2001): Osnovne fitocenološke karakteristike važnijih prirodnih livada i pašnjaka Srbije. - Arhiv za poljoprivredne nauke 62:225-234.

[28] Kosic, V.I. Tardella, F.M. Grbesa, D. Skvorc, Z. Catorci, A. (2014): Effects of abandonment on the functional composition and forage nutritive value of a North Adriatic dry grassland community (Cicarija. Croatia). - Applied Ecology and environmental research 12(1):285-299.

[29] Kuusela, E. (2006): Annual and seasonal changes in mineral contents (Ca. Mg. P. K and $\mathrm{Na}$ ) of grazed clover- grass mixtures in organic farming. - Agricultural and FoodScience 15:23-34.

[30] Lazarević, D. Stošić, M. Dajić, Z. Terzić, D. Cvetković, M. (2009): Productivity and quality of plant mass of meadow ass. Danthonietum calycinae depending on the fertilization and utilization time. - Biotechnology in Animal Husbandry 25 (1-2):133-142.

[31] Lazarević, D. Stošić, M. Dinić, B. Lugić, Z. Terzić, D. (2006): Potencijal produkcije sejanih travnjaka u ravničarskom i planinskom području Srbije. - Biotehnology in Animal Husbandry 22:481-488.

[32] LeBauer, D.S. Treseder, K.K. (2008): Nitrogen limitation of net primary productivity in terrestrial ecosystems is globally distributed. - Ecology 89: 371-379.

[33] Louault, F. Soussana, J.F. Perrodin, M. (2002): Long-term effects of a reduced herbage use in a semi-natural grassland. I. Plant functional traits and plant response groups. - In: Durand, J.L. Emile, J.C. Huyghe, C. Lemaire, G. (eds.) Multi-function grasslands: quality forages. animal products and landscapes. Proceedings of the 19th General Meeting of the 
European Grassland Federation. La Rochelle. France. 27-30 May 2002 Grassland Science in Europe 7: 338-339.

[34] Malhi, S.S. Soon, Y.K. Nyborg M. (2010): Long-term effects of balanced fertilization on grass forage yield quality and nutrient uptake soil organic $\mathrm{C}$ and $\mathrm{N}$ and some soil quality characteristics. - Nutrient Cycling in Agroecosystems 86: 425-438.

[35] Nešić, Z. Tomić, Z. Mrfat-Vukelić, S. Žujović, M. (2004): Kvalitet prirodnih travnjaka na području Stare planine. - Acta Agriculturae Serbica 17:243-247.PNAS. 96:1175-1180.

[36] Nevens, F. Rehuel, D. (2003): Effects of cutting or grazing grass swards on herbage yield, nitrogen uptake and residual soil nitrate at different levels of $\mathrm{N}$ fertilization. - Grass and Forage Science 58:431-449.

[37] Perbandt, D. Fricke, T. Wachendorf, M. (2010): Effects of changing simulated sky cover on hyperspectral reflectance measure- ments for dry matter yield and forage quality prediction. - Computers and Electronics in Agriculture 73: 230-239.

[38] Pontes, L.S. Carrère, P. Andueza, D. Louault, F. Soussana, J. F. (2007): Seasonal productivity and nutritive value of temperate grasses found in semi-natural pastures in Europe: responses to cutting frequency and N supply, Grass and Forage Science. - The Journal of the British Grassland Society 62 (4):485-496.

[39] Prentović, T. Djabirski, V. Pacinovski, N. Cilev, G. (2007): Hranjiva vrijednost pašnjaka pehevske regije R. Makedonije. Krmiva. Zagreb. 49:171-175.

[40] Radić, V. Drinić, M. Kralj, A. (2014): Production capabilities and nutritive value of fodder for animal nutrition in mountainous area of Republic of Srpska. - V International Agricultural Symposium "Agrosym 2014"Jahorina:69-74.

[41] Rena, H. Hanc, G. Schönbach, P. Gierus, M. Taube, F. (2016): Forage nutritional characteristics and yield dynamics in a grazed semiarid steppe ecosystem of Inner Mongolia, China. - Ecological Indicators 60:460-469.

[42] Roukos, C. Papanikolaou, K. Karalazos, A. Chatzipanagiotou, A. Mountousis, I. Mygdalia. A. (2011): Changes in nutritional quality of herbage botanical components on a mountain side grassland in North-West Greece. - Animal Feed Science and Technology 169:24-34.

[43] Roukos, C. Papanikolaou, K. Karalazos, A. Chatzipanagiotou, A. Mountousis, I. Mygdalia, A. (2011): Changes in nutritional quality of herbage botanical components on a mountain side grassland in North-West Greece. - Animal Feed Science and Technology 169:24-34.

[44] Saint Pierre, C. C.A Busso, O.A. Montenegro, G.D. Rodríguez, H.D. Giorgetti, T. Montani, O. Bravo (2004). Direct assess- ment of competitive ability nad defoliation tolerance in perennial grasses. - Canadian Journal of Plant Science 84: 195-204.

[45] Salette, J. (1982): The role of fertilizers in improving herbage quality and optimization of its utilization. In: Optimizing yields - the role of fertilizers. - Proceedings of $12^{\text {th }}$ Congress International Potash Institute, Berne, Switzerland:117-144.

[46] Snyman, H.A. (2002): Short-term response of rangeland botanical composition and productivity to fertilization ( $\mathrm{N}$ and $\mathrm{P}$ ) in a semi-arid climate of South Africa. - J. Arid Environ. 50:167-183.

[47] Soder, K.J. Stout, W.L. (2003): Effect of soil type and fertilization level on mineral concentration of pasture: potential relationships to ruminant performance and health. - Journal of Animal Science 81:1603-1610.

[48] Steinfeld, H.Gerber, P.Wassenaar, T.Castel, V. Rosales, M.deHaan,C. (2006): Livestocks long shadow: environmental issues and options. - FAO, Rome, Italy.

[49] Stevanović, D. Jakovljević, M. Vrbničanin, S. Aćić, S. (2004): Hemijski sastav sena prirodnih travnjaka Zlatibora u zavisnosti od sastava zemljišta. - Acta Agriculturae Serbica 17:235-241. 
[50] Stybnarova, M. Halk, J. Micova, P. Kararcova, H. Latal, O. Fiala, K. Pozdisek, J. (2015): Species Diversity and Botanical Composition of Permanent Grassland as a Response to Different Grazing Management Practices. -Acta Univ. Agric. Silvic. Mendelianae Brun.

[51] Szentes, Sz. Sutyinszki, Zs. Szabó, G. Zimmermann, Z. Házi, J. Wichmann, B. Hufnágel, L. Penksza, K. Bartha, S. (2012): Grazed Pannonian grassland beta-diversity changes due to $\mathrm{C} 4$ yellow bluestem. - Cent. Eur. J. Biol. 7(6):1055- 1065.

[52] Underwood, E.J. Suttlen, F. (1999): The mineral nutrition of livestock. - Wallingford. UK: CABI Publishing.

[53] Van Soest, P.J. Robertson, J.B.. Lewis, B.A. (1991): Methods for dietary fibre. neutral detergent fibre in relation to animal nutrition. - J. Dairy Sci. 74:3583-3597.

[54] Verlinden, G. T. Coussens, A. De Vliegher, G. Baert \& G. Haesaert (2010): Effect of humic substances on nutrient uptake by herbage and on production and nutritive value of herbage from sown grass pastures.- GrassandForageScience 65:133-144.

[55] Vitousek, P.M. Howarth, R.W. (1991): Nitrogen limitation on land and in the sea: how can it occur. - Biogeochemistry 13:87-115.

[56] Vučković, S. Simić, A. Ćupina, B. Krstić, Đ. Durović, D. (2010): Effecr of mineral fertilization on yield of Agroseietum vulgaris tyspe meadows in mountainous grasslands in Serbia. - Biotechnology in Animal Husbandry 26:389-394.

[57] Vučković, S. Simić, A. Ćupina, B. Stojanović Ivana. Stanisavljević, R. Vojin, S. Dubljević, R. (2004): Uticaj đubrenja azotom na produktivnost Cynosuretum cristati na Sjeničkopeštersko visoravni. - Acta Agriculturae Serbica 17:279-287.

[58] Wen, L. Dong, S.K. Li, Y.Y. Pulver, C. Li, X.Y. Shi, J.J. Wang, Y.L. Ma, Y.S. Liu, D.M. (2013) : Variation of botanical composition. forage production and nutrient values along a grassland degradation gradient in the alpine region of Qinghai-Tibet Plateau. Phyton (B. Aires) 82 (1):45-54.

[59] Wen, L. Dong, S.K. Li, Y.Y. Pulver, C. Li, X.Y. Shi, J.J. Wang, Y.L. Ma, Y.S. Liu, D.M. (2013): Variation of botanical composition, forage production and nutrient values along a grassland degradation gradient in the alpine region of Qinghai-Tibet Plateau. - PHYTON, International Journal of experimental botany 82: 45-54.

[60] White, F. (1983): The vegetation of Africa. Natural Resources Research. UNESCO. Paris. 20:356

[61] Wright, I.A. Jones, J.R. Davies, D.A. Davidson, G.R. Vale, J.E. (2006): The effect of sward surface height on the response to mixed grazing by cattle and sheep. - Animal Science 82:271-276.

[62] Yang, Y. Fang, J. Smith, P. Tang, Y. Chen, A. Ji, C. Hu, H. Rao, S. Tan, K. He, J. S. (2009): Changes in topsoil carbon stock in the Tibetan grasslands between the 1980s and 2004. - Global Change Biology 15:2723-2729. 